\title{
Elemental metals for environmental remediation: Learning from cementation process
}

Noubactep C.

Angewandte Geologie, Universität Göttingen, Goldschmidtstraße 3, D - 37077 Göttingen, Germany. e-mail: cnoubac@gwdg.de; Tel. +49 55139 3191, Fax: +49 551399379

\section{Abstract}

The further development of $\mathrm{Fe}^{0}$-based remediation technology depends on the profound understanding of the mechanisms involved in the process of aqueous contaminant removal.

The view that adsorption and co-precipitation are the fundamental contaminant removal mechanisms is currently facing a harsh scepticism. Results from electrochemical cementation are used to bring new insights in the process of contaminant removal in $\mathrm{Fe}^{0} / \mathrm{H}_{2} \mathrm{O}$ systems. The common feature of hydrometallurgical cementation and metal-based remediation is the heterogeneous nature of the processes which inevitably occurs in the presence of a surface scale. The major difference between both process is that the surface of remediation metals is covered by layers of own oxide(s) while the surface of the reducing metal in covered by porous layers of the cemented metal. The porous cemented metal is necessarily electronic conductive and favours further dissolution of the reducing metal. For the remediation metal, neither a porous layer nor a conductive layer could be warrant. Therefore, the continuation of the remediation process depends on the long-term porosity of oxide scales on the metal surfaces. These considerations rationalized the superiority of $\mathrm{Fe}^{0}$ as remediation agent compared to thermodynamically more favourable $\mathrm{Al}^{0}$ and $\mathrm{Zn}^{0}$. The validity of the adsorption/co-precipitation concept is corroborated.

Key words: Adsorption; Cementation, Co-precipitation; Surface scale; Zerovalent Iron.

Capsule: Hydrometallurgy teaches that sustaining oxide scale formation and transformation on $\mathrm{Fe}^{0}$ is the best way to warrant long service life of iron walls. 
27 The use of metallic iron $\left(\mathrm{Fe}^{0}\right)$ for environmental remediation is now well established [1-4].

However, the exact mechanism of aqueous contaminant removal in the presence of $\mathrm{Fe}^{0}$ is not fully understood. It is univocally accepted that contaminant removal is due to the process of iron oxidative dissolution (iron corrosion). However, a net discrepancy exists on the role of the oxide scale on $\mathrm{Fe}^{0}$ in the process of contaminant removal. Oxide scale formation on $\mathrm{Fe}^{0}$ at $\mathrm{pH}>4.5$ is a fundamental characteristic of aqueous iron corrosion [5-8]. The universal oxide scale on $\mathrm{Fe}^{0}$ is either regarded as beneficial (blessing) or inhibitory (curse) for aqueous contaminant removal in the presence of $\mathrm{Fe}^{0}$.

The prevailing concept was introduced in the early phase of investigations regarding the mechanism of aqueous contaminant removal by $\mathrm{Fe}^{0}[9,10]$. This concept considers that contaminant is removed mainly by an heterogeneous chemical reduction, ideally at the surface of $\mathrm{Fe}^{0}$. Accordingly, the oxide scale on $\mathrm{Fe}^{0}$ is a curse as its represents a diffusion barrier slowing down the kinetics of contaminant removal $[11,12]$. The initial model assuming the local existence of oxide-free $\mathrm{Fe}^{0}$ in the aqueous solution was proven unrealistic by Bonin et al. [13]. A new conceptual model for the reductive transformation was proposed $[13,14]$. The conceptual model of Bonin et al. [13] indicated that the reductive transformation is controlled by electron transfer through the surface film. Accordingly the film must be electronic conductive. However, no such conductive film is expected in nature $[6,15,16]$. Moreover, the concept regarding oxide-scale as curse is built on the premise that $\mathrm{Fe}^{0}$ is a strong reducing agent. The concept is strictly applicable only to reducible contaminants.

It is important to notice that the reductive transformation concept has never been univocally accepted $[17,18]$. For example, Warren et al. [18] wrote that "a convincing mechanism for the reductive dehalogenation of haloorganics by zero-valence metals has not yet been proposed. Matheson and Tratnyek [9] maintained that dehalogenation was not mediated by $\mathrm{H}_{2}(\mathrm{~g})$ or $51 \mathrm{Fe}(\mathrm{II})$ in the bulk aqueous-phase solution, suggesting that observed reactions take place at the 
metal surface.” Three years later, O'Hannesin and Gillham [1] acknowledged that "there is a broad consensus that the process is an abiotic redox reaction involving reduction of the organic compound and oxidation of the metal”. Despite this "broad consensus”, the reductive transformation concept has felt to explain many experimental observations [19-21].

An alternative concept regards the oxide scale on $\mathrm{Fe}^{0}$ as beneficial (a blessing) for the process of aqueous contaminant removal [22-25]. Independent researchers could traceably demonstrate that quantitative contaminant removal is only observed when iron corrosion products are allowed to precipitate in the system [26-31]. Their results suggest that adsorption and co-precipitation are the fundamental (not the dominant or the major) contaminant removal mechanisms. Accordingly, relevant contaminants could be further (quantitatively) chemically transformed (reduced or oxidized). The first merit of this concept it that its explains why a contaminant like zinc which is non reducible by $\mathrm{Fe}^{0}$ (Tab. 1) could be quantitatively removed in the presence of $\mathrm{Fe}^{0}$ [32].

The present communication is motivated by recent publications speaking disparagingly about the concept of adsorption/co-precipitation as fundamental mechanisms of aqueous contaminant removal in the presence of $\mathrm{Fe}^{0}[33,34]$. The similarities between aqueous contaminant removal by $\mathrm{Fe}^{0}$ and metal iron cementation on elemental metals (mostly $\mathrm{Al}^{0}, \mathrm{Fe}^{0}$, $\mathrm{Zn}^{0}$ ) will be discussed with the aim to present results from the hydrometallurgical process of cementation which could help to understand and further develop the process of aqueous contaminant removal by $\mathrm{Fe}^{0}$. Both processes are heterogeneous and the metal surface is covered by a scale acting as diffusion barrier. For the sake of clarity the diffusion barrier in the $\mathrm{Fe}^{0}$ remediation will first be presented.

\section{Aqueous contaminant removal by metallic iron}

Aqueous iron corrosion on which remediation with metallic iron is based is an heterogeneous electrochemical process. A simplistic mechanism for iron oxidative dissolution involves four major steps: (i) diffusion of the oxidizing agent $\left(\mathrm{H}^{+}, \mathrm{O}_{2}\right.$, contaminant) to the $\mathrm{Fe}^{0}$ surface, (ii) 
adsorption of the oxidizing agent onto the iron surface, (iii) the reduction of the oxidizing agent, and (iv) diffusion of reaction products (including $\mathrm{Fe}^{\mathrm{II}}$ species) away from the reactive site on $\mathrm{Fe}^{0}$. Because aqueous iron corrosion (at $\mathrm{pH}>4.5$ ) is always coupled to the formation of an oxide scale on the $\mathrm{Fe}^{0}$ surface, the rate of the oxidizing agent diffusion to the iron surface is necessarily the limiting step for the corrosion process which is said to be "diffusion controlled" [7,16]. If, the rate of iron corrosion were limited by the adsorption or electron transfer steps, the reaction would be said to be "chemical controlled", "surface controlled”, or “reaction controlled” (reaction-limited).

The presentation above recalled, that iron corrosion at $\mathrm{pH}>4.5$ is a "diffusion controlled" or mass transfer limited process. Accordingly, there should have been no need to discuss the active form of rate control in the process of contaminant removal in the presence of metallic iron under subsurface conditions. Clearly, attempts to determine whether the process of contaminant removal in the presence of $\mathrm{Fe}^{0}$ in a field reactive wall is mass transfer or reaction-limited $[9,17,35]$ was not necessary as this was well-documented before the event of the iron remediation technology [25].

In batch experiments or fluidised beds, the rate of contaminant removal by $\mathrm{Fe}^{0}$ could be increased by increasing the mass transfer using various mixing operations (e.g. agitation, stirring, vibration) [36,37]. However, one should acknowledge that such mixing operations are not applicable to packed beds and field reactive walls [25,36,38]. As discussed in details elsewhere [25], the use of various mixing systems with the resulting mixing intensities and their impact on the process of contaminant removal in the presence of $\mathrm{Fe}^{0}$ is the main reason why the inconsistent concept of reductive transformation has survived for more than a decade. The example of the usefulness of mixing operations in investigating processes involving iron corrosion reveals that care must be taken while using well-documented results from other branches of science in designing experiments and/or interpreting new experimental data. A further example is the way to experimentally evidence a chemically controlled reaction. To 
demonstrate the occurrence of a chemical reaction in a system, the temperature of the system

105 should be varied. An increased reaction rate with increasing temperature is a strong proof for

106 chemical reaction [39]. However, increased contaminant removal with increasing temperature

107 is not necessarily coupled to contaminant reduction by $\mathrm{Fe}^{0}$ as water is also an oxidizing agent

108 and resulting corrosion products are contaminant scavengers. In other words, contaminant

109 removal might only indirectly be coupled to proven chemical reactions.

110 The present communication aims at presenting some aspects of the electrochemical

111 cementation process as used in the hydrometallurgy and discuss their usefulness for metallic

112 iron as currently used in environmental remediation. Two particular aspects will be discussed

113 in some details: (i) the differential reactivity and the suitability of aluminium, iron and zinc as

114 removing agent, and (ii) the proper consideration of the surface scale on $\mathrm{Fe}^{0}$. For the sake of

115 clarity the process of cementation will be first presented.

\section{Cementation and its use in the hydrometallurgy}

117 Cementation is an electrochemical process by which a more noble metal ion $\left(\mathrm{M}^{\mathrm{n}+}-\mathrm{Eq} .1\right)$ is 118 precipitated from solution and replaced by a metal higher in the electromotive series $\left(\mathrm{M}_{1}{ }^{\mathrm{m}+}\right.$ -

119 Eq. 2) [39-45]. Cementation, also known as contact reduction or metal displacement, is 120 necessarily a spontaneous heterogeneous reaction $\left(\Delta G^{0}<0\right)$ that takes place through the 121 galvanic cell $\mathrm{M}_{1}{ }^{0} / \mathrm{M}_{1}^{\mathrm{m}+} / / \mathrm{M}^{\mathrm{n}+} / \mathrm{M}$ (Eq. 3).

$$
\mathrm{m} \mathrm{M}^{\mathrm{n}+}+\mathrm{m} . \mathrm{ne} \mathrm{e}^{-} \Leftrightarrow \mathrm{m} \mathrm{M}^{0}
$$

$$
\mathrm{E}^{0}(\mathrm{~V})
$$

$$
\Delta \mathrm{G}^{0}=-\mathrm{z} \cdot \mathrm{F} \cdot \Delta \mathrm{E}^{0}
$$

$126 \mathrm{z}=\mathrm{n} . \mathrm{m}$ is the number of electrons exchanged between $\mathrm{M}_{1}$ and $\mathrm{M}$ and $\mathrm{F}$ the Faraday's

127 constant.

128 The thermodynamic basis of cementation can be summarized as follows: The standard free energy ( $\Delta \mathrm{G}^{0}$ - Eq. 4) of the cementation process after Eq. 3 must be negative (spontaneous 
reaction). This requires that $\Delta \mathrm{E}^{0}$ is positive or $\mathrm{E}_{1}{ }^{0}<\mathrm{E}^{0}$. In order words, cementation consists

131 in the spontaneous heterogeneous reduction of a metallic ion present in solution $\left(\mathrm{M}^{\mathrm{n}+}\right)$ by a

132 more electropositive sacrificial metal $\left(\mathrm{M}_{1}^{0}\right) . \mathrm{M}_{1}$ is the metal higher in the electromotive series

133 (Table 1). It is evident from table 1 that, from a pure thermodynamic perspective, $\mathrm{Al}$ should

134 be the most powerful metal for cementation followed by $\mathrm{Zn}$ and Fe. However as will be

135 discussed later the stability of the oxide scale on the individual metals is determinant for the 136 progress of their oxidative dissolution.

137 Cementation is one of the most effective and economic techniques for removing valuable 138 metals from industrial effluents $[43,44,45,47,48]$. The technique is affordable because of its

139 relative simplicity, ease of control, and low energy consumption. A cementation reaction is an

140 heterogeneous processes limited by diffusion through the mass transfer boundary layer.

141 However, unlike many other heterogeneous reaction systems, cementation reactions are

142 unique in that the reaction product usually does not impede the reaction progress but rather

143 frequently enhances the reaction kinetics ([49] and references therein). Discussing the

144 differential impact of diffusion layers on metals in cementation and contaminant removal is

145 the major reason for this communication and will be presented below. The major difference

146 between both processes relies in the intrinsic nature of each process. However both processes

147 are based on the same concept: The electrochemical reduction. Cementation is a technological

148 process for which the experimental conditions could be case specific optimised. Contaminant

149 removal should be operated on a case-specific basis without changing the chemistry of the

150 system. From this difference it arises that the $\mathrm{pH}$ value (and thus the nature of the surface 151 scale) and the mixing operation could be regarded as the two key factors for the design of 152 each system. The further presentation will be focussed on Al, Fe and Zn.

1534 Cementation using Al, Fe and Zn

154 The control of the $\mathrm{pH}$ value is a key task for the cementation process for a variety of reasons

155 including: (i) corrosion damage of reactors, (ii) excess dissolution of the reducing metal (Al, 
156 Fe and Zn), and (iii) hydroxide precipitation. Accordingly, the determination of the optimal $157 \mathrm{pH}$ value is an important economical issue for any cementation plant. The impact of $\mathrm{pH}$ on 158 the performance of $\mathrm{Al}, \mathrm{Fe}$ and $\mathrm{Zn}$ as reducing metal will be discussed on the basis of the 159 results from $\mathrm{Hg}^{2+}$ cementation by $\mathrm{Al}^{0}, \mathrm{Fe}^{0}$ and $\mathrm{Zn}^{0}$ [50]. The experiments were performed for 16030 minutes in Erlenmeyer's, with an initial mercury concentration equal to $500 \mathrm{mg} / \mathrm{L}$ and 161 using $10 \mathrm{~mol}$ of reducing agent for each mol of mercury. The $\mathrm{pH}$-dependent evolution of the system was recorded (Fig. 1). Figure 1a represents the variation of final $\mathrm{pH}$ value as function of the initial $\mathrm{pH}$ for three parallel experiments. Figure $1 \mathrm{~b}$ represents the variation of the molar ratio dissolved reducing metal to the cemented $\mathrm{Hg}$ as function of the initial $\mathrm{pH}$. The stoichiometric ratio is 1.00 for $\mathrm{Zn}$ and $\mathrm{Fe}$ and 0.67 for $\mathrm{Al}$.

166 Figure 1a clearly shows that, $\mathrm{pH}$ stabilises at a constant value for $\mathrm{Al}$ (4.7) and Fe (3.7) 167 whereas the $\mathrm{pH}$ in the system with $\mathrm{Zn}$ was still varying (after $30 \mathrm{~min}$ ). This behaviour is 168 strongly related to the amount of reducing metal dissolved. Accordingly the order of 169 increasing reactivity based on metal dissolution is: $\mathrm{Fe}<\mathrm{Al}<\mathrm{Zn}$. Remember that the order of 170 increasing reactivity based on the electrode potential was: $\mathrm{Fe}<\mathrm{Zn}<\mathrm{Al}$. The difference is 171 certainly due to the differential hydrolysis and solubility behaviour of resulted metallic ions $172\left(\mathrm{Al}^{3+}, \mathrm{Fe}^{2+} / \mathrm{Fe}^{3+}, \mathrm{Zn}^{2+}\right)$ and the adherence of resulting metal oxides to basic surface. These 173 issues will not be discussed here. The most important feature from the pH-dependant 174 cementation is to find the optimal $\mathrm{pH}$ for the optimal yield which is ideally the $\mathrm{pH}$ where the 175 stoichiometry of the reaction approaches the theoretical value ( 0.67 for $\mathrm{Al}$ and 1.00 for Fe and 176 Zn).

177 Figure $1 \mathrm{~b}$ shows that, the optimal $\mathrm{pH}$ regions are 5.0 - 6.0 for $\mathrm{Al}, 3.0$ - 5.0 for $\mathrm{Fe}$, and 4.0 $178 \quad 7.0$ for $\mathrm{Zn}$. It should be further considered that as $\mathrm{pH}$ value increases the precipitation of metal 179 hydroxides is progressively significant. Metal hydroxides are known for their adsorptive 180 properties which are disturbing for the cementation process. Based on these considerations, 
181 Anacleto and Carvalho [50] performed their $\mathrm{Hg}^{2+}$ cementation reaction under following

182 conditions: aluminium (3.0 - 4.0), iron (3.0), and zinc (4.0 - 6.0).

$183 \quad 4.1 \quad$ Nature of the diffusion layer on reducing metals

184 The presentation above clearly shows that cementation is optimally performed under

185 conditions where ions from the reducing metal (here, $\mathrm{Al}^{3+}, \mathrm{Fe}^{2+} / \mathrm{Fe}^{3+}, \mathrm{Zn}^{2+}$ ) are soluble and do

186 not readily hydrolyse and precipitate. The precipitating elemental metal (e.g. $\mathrm{Hg}^{0}$ ) is

187 necessarily insoluble. Therefore, precipitating metals accumulate at the surface of the

188 reducing metal $\left(\mathrm{Al}^{0}, \mathrm{Fe}^{0}\right.$ or $\left.\mathrm{Zn}^{0}\right)$. This metallic layer is porous, and dendritic and thus

189 significantly enhances kinetics of the reaction [41,49]. In essence, only a smooth, coherent

190 deposit can inhibit the cementation reaction. According to Power and Ritchie [40],

191 cementation reactions whose constituent half-reactions have electrode potentials which differ

192 by greater than $0.36 \mathrm{~V}$ are likely to be diffusion-controlled (Tab. 1). As recalled above the

193 diffusion is favoured by the porous nature of the metallic deposit which is additionally

194 electronic conductive and constitute a path for electron transport. In other words, the

195 cementation process continues despite the metallic scale for two main reasons: (i) metallic

196 ions are soluble and transported through the porous layer to the bulk solution, (ii) the metallic

197 layer (cemented deposit) is electronic conductive. Consequently, for contaminant reduction to

198 be quantitative in a $\mathrm{Fe}^{0} / \mathrm{H}_{2} \mathrm{O}$ system, the oxide scale should be electronic conductive and 199 porous.

\section{Diffusion layers on remediation elemental metals}

201 Diffusion is a spontaneous process involving mobility of species due to the existence of a 202 concentration gradient in a system. The extend of diffusion depend on (i) the properties of the 203 diffusing species (including their size), and (ii) the structure of the diffusion layer 204 (connectivity, morphology, porosity, pore site distribution or tortuosity). Here the diffusion 205 layer is a precipitated scale (oxide scale). 
Oxide layers on remediation metals are formed at $\mathrm{pH}>5.0$ which is the $\mathrm{pH}$ of natural waters

207 (assuming comparable redox potential). Upon immersion in an aqueous solution, any reactive

metal is instantaneously covered by an oxide scale [6]. The initial scale is possibly porous

(non-protective film) but may be more or less rapidly transformed to an impervious scale

(protective film). The porosity of the oxide scale is very determinant for the progress of metal oxidative dissolution which is coupled to oxide scale formation and contaminant removal.

212 It is well-documented that upon immersion, the surface of aluminium is rapidly covered by a very thin and adherent layer of oxide (protective layer). Accordingly, despite theoretical

(Fig. 1a), $\mathrm{Zn}$ is the most efficient cementation agent because of its more rapid dissolution.

216 However, because $\mathrm{Zn}^{\mathrm{II}}$ is the only soluble $\mathrm{Zn}$ species, the progress of the dissolution will 217 yield to a formation of a dense oxide film on $\mathrm{Zn}^{0}$ which will progressively develop to an 218 impervious layer with the time. For $\mathrm{Fe}^{0}$, the existence of two soluble species $\left(\mathrm{Fe}^{\mathrm{II}}\right.$ and $\mathrm{Fe}^{\mathrm{III}}$ ) 219 and several iron oxides with different crystal structures [24] is a guarantee for the long term 220 non-protectiveness. Accordingly, $\mathrm{Fe}^{0}$ is best remediation agent. The non toxic nature of iron 221 species and the lost-cost of $\mathrm{Fe}^{0}$ materials are further reasons for its intensive use as 222 remediation agent.

\section{Concluding remarks}

224 The formation of surface scale on immersed elemental metals is a common feature for 225 remediation with metallic elements and electrochemical cementation (Tab. 2). In both cases 226 the surface scale primarily inhibits the metal dissolution and thus the kinetics of the concerned 227 process. The formation of an oxide film on the cementation agent can be prevented (or 228 limited) by a rational selection of the operational conditions (e.g. $\mathrm{pH}$ value, amount of 229 cementation agent, and mixing operations). Provided these operational conditions are 230 accurately selected, the cementation process should not be essentially inhibited by the metal 231 deposit which is even beneficial in some cases [43,45,50]. 
The avoidance of the oxide scale formation on elemental metals under natural conditions is

233 not possible. Therefore, one could only discuss or access their porosity and their electronic conductivity. As a rule an electronic conductive oxide scale can not be expected under environmental conditions. In fact, regardless from the availability and abundance of molecular oxygen (anoxic or oxic conditions), $\mathrm{Fe}^{0}$ is always covered by a multi-layer of oxide 237 and hydroxide mixture of which only magnetite $\left(\mathrm{Fe}_{3} \mathrm{O}_{4}\right)$ and unstable forms (FeO, green rusts) 238 are electronic conductive. Consequently, the reactivity of $\mathrm{Fe}^{0}$ for environmental remediation 239 is mostly due to the porosity of the oxide scale and factors influencing its evolution (e.g. $\mathrm{pH}$ 240 value, water salinity, nature of contaminants). To sustain $\mathrm{Fe}^{0}$ reactivity under environmental 241 conditions, appropriate reactive materials should be selected or manufactured. In this regard, 242 porous composites like those used in SONO arsenic filters could be used [51,52].

243 In conclusion, a careful consideration of the optimal conditions for the hydrometallurgical 244 process of cementation using $\mathrm{Al}^{0}, \mathrm{Fe}^{0}$, and $\mathrm{Zn}^{0}$ has enabled the precision of the role of oxide scale in the process of contaminant removal with the same metals. Its appears that considering 246 the oxide scale as a curse for the remediation process was a mistake. The oxide scale is rather 247 beneficial for the process of contaminant removal by $\mathrm{Fe}^{0}$. Moreover, removed contaminants 248 and their potential reaction products are progressively enmeshed in the matrix of ageing 249 corrosion products and are very stable under natural conditions. Accordingly, instead of 250 maintaining an inconsistent concept [33,34,53,54], the scientific community should focus his 251 attention on ways to sustain the corrosion process rather to try to free the $\mathrm{Fe}^{0}$ from 252 spontaneously generated corrosion products. It should be observed that operational tools 253 presently used to sustain $\mathrm{Fe}^{0}$ reactivity such as: (i) using smaller particle size of $\mathrm{Fe}^{0}$ (including 254 nano-scale $\mathrm{Fe}^{0}$ ), (ii) mixing experimental systems or (iii) using bimetallic systems all result in 255 increased corrosion products generation. Accordingly, all these tools corroborate the 256 adsorption/co-precipitation concept.

\section{References}


258 [1] S.F. O’Hannesin, R.W. Gillham, Long-term performance of an in situ "iron wall" for remediation of VOCs, Ground Water 36 (1998) 164-170.

260 [2] A.D. Henderson, A.H. Demond, Long-term performance of zero-valent iron permeable reactive barriers: a critical review, Environ. Eng. Sci. 24 (2007) 401-423.

[3] A.B. Cundy, L. Hopkinson, R.L.D. Whitby, Use of iron-based technologies in contaminated land and groundwater remediation: A review, Sci. Tot. Environ. 400 (2008) 42-51.

[4] R. Thiruvenkatachari, S. Vigneswaran, R. Naidu, Permeable reactive barrier for groundwater remediation, J. Ind. Eng. Chem. 14 (2008) 145-156.

[5] E.R. Wilson, The Mechanism of the corrosion of iron and steel in natural waters and the calculation of specific rates of corrosion, Indust. Eng. Chem. 15 (1923 ) 127-133.

[6] U.R. Evans, The distribution and velocity of the corrosion of metals, J. Franklin Inst. 208 (1929) 45-58.

[7] M. Stratmann, J. Müller, The mechanism of the oxygen reduction on rust-covered metal substrates, Corros. Sci. 36 (1994) 327-359.

[8] M. Odziemkowski, Spectroscopic studies and reactions of corrosion products at surfaces and electrodes, Spectrosc. Prop. Inorg. Organomet. Compds. (2009), doi: 10.1039/b715004k.

[9] L.J. Matheson, P.G. Tratnyek, Reductive dehalogenation of chlorinated methanes by iron metal, Environ. Sci. Technol. 28 (1994) 2045-2053.

[10] E.J. Weber, Iron-mediated reductive transformations: investigation of reaction mechanism, Environ. Sci. Technol. 30 (1996) 716-719.

[11] T.L. Johnson, W. Fish, Y.A. Gorby, P.G. Tratnyek, Degradation of carbon tetrachloride by iron metal: Complexation effects on the oxide surface, J. Cont. Hydrol. 29 (1998) 379-398. 
[12] M.M. Scherer, S. Richter, R.L. Valentine, P.J.J. Alvarez, Chemistry and microbiology of permeable reactive barriers for in situ groundwater clean up, Rev. Environ. Sci. Technol. 30 (2000) 363-411.

[13] P.M.L. Bonin, M.S. Odziemkowski, R.W. Gillham, Influence of chlorinated solvents on polarization and corrosion behaviour of iron in borate buffer, Corros. Sci. 40 (1998) 1391-1409.

[14] M.S. Odziemkowski, T.T. Schuhmacher, R.W. Gillham, E.J. Reardon, Mechanism of oxide film formation on iron in simulating groundwater solutions: raman spectroscopic studies, Corros. Sci. 40 (1998) 371-389.

[15] E.J. Caule, M. Cohen, The formation of thin films of iron oxide, Can. J. Chem. 33 (1955), 288-304.

[16] M. Cohen, The formation and properties of passive films on iron. Can. J. Chem. 37 (1959) 286-291.

[17] K.D. Warren, R.G. Arnold, T.L. Bishop, L.C. Lindholm, E.A. Betterton, Kinetics and mechanism of reductive dehalogenation of carbon tetrachloride using zero-valence metals, J. Hazard. Mater. 41 (1995) 217-227.

[18] B.K. Lavine, G. Auslander, J. Ritter, Polarographic studies of zero valent iron as a reductant for remediation of nitroaromatics in the environment, Microchem. J., 70 (2001) 69-83.

[19] R. Mantha, K.E. Taylor, N. Biswas, J.K. Bewtra, A continuous system for $\mathrm{Fe}^{0}$ reduction of nitrobenzene in synthetic wastewater, Environ. Sci. Technol. 35 (2001) 3231-3236.

[20] G. Lee, S. Rho, D. Jahng, Design considerations for groundwater remediation using reduced metals, Korean J. Chem. Eng., 21 (2004) 621-628.

[21] J.A. Mielczarski, G.M. Atenas, E. Mielczarski, Role of iron surface oxidation layers in decomposition of azo-dye water pollutants in weak acidic solutions, Appl. Catal. B 56 (2005) 289-303. 
[22] C. Noubactep, Processes of contaminant removal in " $\mathrm{Fe}^{0}-\mathrm{H}_{2} \mathrm{O}$ " systems revisited. The importance of co-precipitation, Open Environ. J. 1 (2007) 9-13.

[23] C. Noubactep, A critical review on the mechanism of contaminant removal in $\mathrm{Fe}^{0}-\mathrm{H}_{2} \mathrm{O}$ systems, Environ. Technol. 29 (2008) 909-920.

[24] C. Noubactep, The suitability of metallic iron for environmental remediation, Environ. Progr. (2010) doi: 10.1002/ep.10406.

[25] C. Noubactep, A. Schöner, M. Sauter, Significance of oxide-film in discussing the mechanism of contaminant removal by elemental iron materials, In "PhotoElectrochemistry \& Photo-Biology for the Sustainablity"; S. Kaneco, B. Viswanathan, H. Katsumata (Eds.), Bentham Science Publishers 1 (2010) 34-55.

[26] C. Noubactep, G. Meinrath, P. Dietrich, B. Merkel, Mitigating uranium in ground water: prospects and limitations, Environ. Sci. Technol. 37 (2003) 4304-4308.

[27] C. Noubactep, G. Meinrath, J.B. Merkel, Investigating the mechanism of uranium removal by zerovalent iron materials, Environ. Chem. 2 (2005) 235-242.

[28] C. Noubactep, A. Schöner, G. Meinrath, Mechanism of uranium (VI) fixation by elemental iron', J. Hazard. Mater. 132 (2006) 202-212.

[29] A. Ghauch, A. Tuqan, Reductive destruction and decontamination of aqueous solutions of chlorinated antimicrobial agent using bimetallic systems, J. Hazard. Mater. 164 (2009) 665-674.

[30] C. Noubactep, Characterizing the discoloration of methylene blue in $\mathrm{Fe}^{0} / \mathrm{H}_{2} \mathrm{O}$ systems, $\mathrm{J}$. Hazard. Mater. 166 (2009) 79-87.

[31] A. Ghauch, H.A. Assi, A. Tuqan, Investigating the mechanism of clofibric acid removal in $\mathrm{Fe}^{0} / \mathrm{H}_{2} \mathrm{O}$ systems, J. Hazard. Mater. 176 (2010) 48-55.

[32] S.J. Morrison, D.R. Metzler, B.P. Dwyer, Removal of As, Mn, Mo, Se, U, V and Zn from groundwater by zero-valent iron in a passive treatment cell: reaction progress modeling, J. Contam. Hydrol. 56 (2002) 99-116. 
[33] N. Zhu, H. Luan, S. Yuan, J. Chen, X. Wu, L. Wang, Effective dechlorination of HCB by nanoscale Cu/Fe particles, J. Hazard. Mater. 176 (2010) 1101-1105.

[34] P.G. Tratnyek, A.J. Salter, Response to comment on "degradation of 1,2,3trichloropropane (TCP): hydrolysis, elimination, and reduction by iron and zinc”, Environ. Sci. Technol. 44 (2010) 3198-3199.

[35] S. Choe, Y.Y. Chang, K.Y. Hwang, J. Khim, Kinetics of reductive denitrification by nanoscale zero-valent iron, Chemosphere 41 (2000) 1307-1311.

[36] Y.-M. Chen, C.-W. Li, S.-S. Chen, Fluidized zero valent iron bed reactor for nitrate removal, Chemosphere 59 (2005) 753-759.

[37] S.-S. Chen, C.-Y. Cheng, C.-W. Li, P.-H. Chai, Y.-M. Chang, Reduction of chromate from electroplating wastewater from $\mathrm{pH} 1$ to 2 using fluidized zero valent iron process, J. Hazard. Mater. 142 (2007) 362-367.

[38] C. Noubactep, A.-M.F. Kurth, M. Sauter, Evaluation of the effects of shaking intensity on the process of methylene blue discoloration by metallic iron, J. Hazard. Mater. 169 (2009) 1005-1011.

[39] S. Robertson, M. Jeffrey, H. Zhang, E. Ho, An introductory electrochemical approach to studying hydrometallurgical reactions, Metal. Mater. Trans. B 36 (2005) 313-325.

[40] G.P. Power, I.M. Ritchie, A contribution to the theory of cementation (metal displacement) reactions, Australian J. Chem. 29 (1976) 699-709.

[41] W.W. Fisher, Fluidized cathode cementation of copper, Hydrometallurgy 16 (1986) 5567.

[42] F. Habashi, A short history of hydrometallurgy, Hydrometallurgy 79 (2005) 15-22.

[43] M. Karavasteva, Kinetics and deposit morphology of copper cementation onto zinc, iron and aluminium, Hydrometallurgy 76 (2005) 149-152. 
[44] N.K. Amin, E-S.Z. El-Ashtoukhy, O. Abdelwahab, Rate of cadmium ions removal from dilute solutions by cementation on zinc using a rotating fixed bed reactor, Hydrometallurgy 89 (2007) 224-232.

[45] M. Karavasteva, The effect of nonylphenylpolyethylene glycol on the kinetics and morphology of silver cemented using zinc, iron, copper and aluminium, Hydrometallurgy 95 (2009) 337-340.

[46] Y. Gerasimov, V. Dreving, E. Eremin, A. Kiselev, V. Lebedev, G. Panchenkov, A. Shlygin, Physical Chemistry, MIR Moscow (1985) 624 pp.

[47] Z. Wang, D. Chen, L. Chen, Gold cementation from thiocyanate solutions by iron powder, Miner. Eng. 20 (2007) 581-590.

[48] M. Volpe, D. Oliveri, G. Ferrara, M. Salvaggio, S. Piazza, S. Italiano, C. Sunseri, Metallic lead recovery from lead-acid battery paste by urea acetate dissolution and cementation on iron, Hydrometallurgy 96 (2009) 123-131.

[49] G.D. Sulka, M. Jaskula, Study of the mechanism of silver ions cementation onto copper from acidic sulphate solutions and the morphology of the silver deposit, Hydrometallurgy 72 (2004) 93-110.

[50] A.L. Anacleto, J.R. Carvalho, Mercury cementation from chloride solutions using iron, zinc and aluminium, Miner. Eng. 9 (1996) 385-397.

[51] A. Hussam, A.K.M. Munir, A simple and effective arsenic filter based on composite iron matrix: Development and deployment studies for groundwater of Bangladesh, J. Environ. Sci. Health A 42 (2007) 1869-1878.

[52] S. Ahamed, A.K.M. Munir, A. Hussam, Groundwater arsenic removal technologies based on sorbents: Field applications and sustainability. in Handbook of Water Quality and Water Purity, Elsevier Inc. Chapter 16 (2009) 379-417. 
383 [53] L. Gui, S.-W. Jeen, D.W. Blowes, R.W. Gillham, Y.Q. Yang, Reply to the comment on 384 "reduction of chromate by granular iron in the presence of dissolved $\mathrm{CaCO}_{3}$ ” by $\mathrm{C}$. $385 \quad$ Noubactep, Appl. Geochem. 24 (2009) 2208-2210.

386 [54] S.-H. Kang, W. Choi, Response to comment on "oxidative degradation of organic 387 compounds using zero-valent iron in the presence of natural organic matter serving as an 388 electron shuttle”, Environ. Sci. Technol. 43 (2009) 3966-3967.

389 
Table 1: Standard electrode potential of selected metals relevant for hydrometallurgical cementation. Electrode potentials are arranged in increasing order of $\mathrm{E}^{0}$. An electrochemical reaction occurs between an oxidant of higher $\mathrm{E}^{0}$ and a reducing agent of lower $E^{0}$. In other words, a more noble metal ion is precipitated from solution and replaced in solution by a metal higher in the electromotive series. It is clear that the three most powerful reducing agents are $\mathrm{Al}, \mathrm{Zn}$ and $\mathrm{Fe} . \mathrm{E}^{0}$ values are from ref. [46].

\begin{tabular}{|c|c|c|c|c|c|}
\hline \multirow{2}{*}{$\begin{array}{l}\text { Electrode } \\
\mathrm{Al}^{3+} / \mathrm{Al}\end{array}$} & \multicolumn{3}{|c|}{ Reaction } & $\begin{array}{c}\mathbf{E}^{\mathbf{0}} \\
(\mathrm{V})\end{array}$ & Eq. \\
\hline & $\mathrm{Al}^{3+}+3 \mathrm{e}^{-}$ & $\Leftrightarrow$ & $\mathrm{Al}^{0}$ & -1.660 & (5) \\
\hline $\mathrm{Zn}^{2+} / \mathrm{Zn}$ & $\mathrm{Zn}^{2+}+2 \mathrm{e}^{-}$ & $\Leftrightarrow$ & $\mathrm{Zn}^{0}$ & -0.763 & (6) \\
\hline $\mathrm{Fe}^{2+} / \mathrm{Fe}$ & $\mathrm{Fe}^{2+}+2 \mathrm{e}^{-}$ & $\Leftrightarrow$ & $\mathrm{Fe}^{0}$ & -0.440 & (7) \\
\hline $\mathrm{Cd}^{2+} / \mathrm{Cd}$ & $\mathrm{Cd}^{2+}+2 \mathrm{e}^{-}$ & $\Leftrightarrow$ & $\mathrm{Cd}^{0}$ & -0.403 & (8) \\
\hline $\mathrm{Ni}^{2+} / \mathrm{Ni}$ & $\mathrm{Ni}^{2+}+2 \mathrm{e}^{-}$ & $\Leftrightarrow$ & $\mathrm{Ni}^{0}$ & -0.250 & (9) \\
\hline $\mathrm{Pb}^{2+} / \mathrm{Pb}$ & $\mathrm{Pb}^{2+}+23 \mathrm{e}^{-}$ & $\Leftrightarrow$ & $\mathrm{Pb}^{0}$ & -0.126 & (10) \\
\hline $\mathrm{H}^{+} / \mathrm{H}_{2}$ & $2 \mathrm{H}^{+}+2 \mathrm{e}^{-}$ & $\Leftrightarrow$ & $\mathrm{H}_{2}$ & 0.000 & (11) \\
\hline $\mathrm{Cu}^{2+} / \mathrm{Cu}$ & $\mathrm{Cu}^{2+}+2 \mathrm{e}^{-}$ & $\Leftrightarrow$ & $\mathrm{Cu}^{0}$ & 0.337 & (12) \\
\hline $\mathrm{Cu}^{+} / \mathrm{Cu}$ & $\mathrm{Cu}^{+}+\mathrm{e}^{-}$ & $\Leftrightarrow$ & $\mathrm{Cu}^{0}$ & 0.521 & (13) \\
\hline $\mathrm{Pb}^{4+} / \mathrm{Pb}$ & $\mathrm{Pb}^{4+}+4 \mathrm{e}^{-}$ & $\Leftrightarrow$ & $\mathrm{Pb}^{0}$ & 0.700 & (14) \\
\hline $\mathrm{Hg}_{2}{ }^{2+} / \mathrm{Hg}$ & $\mathrm{Hg}_{2}^{2+}+2 \mathrm{e}^{-}$ & $\Leftrightarrow$ & $2 \mathrm{Hg}^{0}$ & 0.789 & (15) \\
\hline $\mathrm{Ag}^{+} / \mathrm{Ag}$ & $\mathrm{Ag}^{+}+\mathrm{e}^{-}$ & $\Leftrightarrow$ & $\mathrm{Ag}^{0}$ & 0.799 & (16) \\
\hline $\mathrm{Hg}^{2+} / \mathrm{Hg}$ & $\mathrm{Hg}^{2+}+2 \mathrm{e}^{-}$ & $\Leftrightarrow$ & $\mathrm{Hg}^{0}$ & 0.854 & (17) \\
\hline $\mathrm{Au}^{3+} / \mathrm{Au}$ & $\mathrm{Au}^{3+}+3 \mathrm{e}^{-}$ & $\Leftrightarrow$ & $\mathrm{Au}^{0}$ & 1.290 & (18) \\
\hline
\end{tabular}


Table 2: Characteristic features of the electrochemical processes of cementation and metalbased remediation. The processes further differ by the fate of the surface scale. While cemented metal deposits are recovered, metal oxides are responsible for contaminant removal but also for porosity loss.

402

\begin{tabular}{lccccc}
\hline Process & Objective & pH & \multicolumn{3}{c}{ Surface scale } \\
& & & nature & porosity & conductivity \\
& & & & & \\
\hline Cementation & Metal recovery & $<5.0$ & Metal & high & high \\
Remediation & Decontamination & $>6.0$ & Metal oxide & variable & low \\
& & & & & \\
\hline
\end{tabular}

403

404

405 
405

406

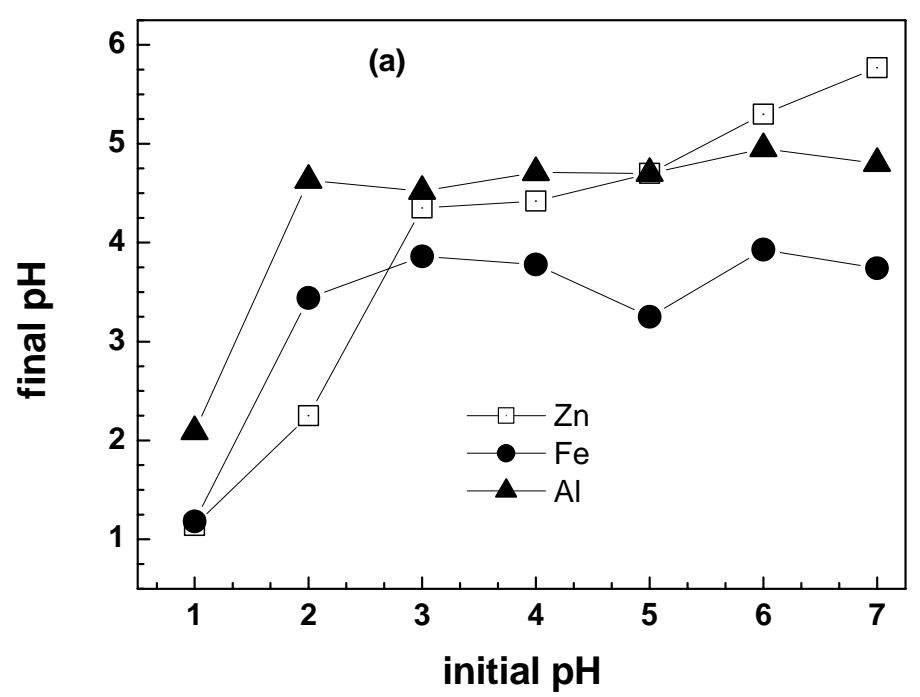

407

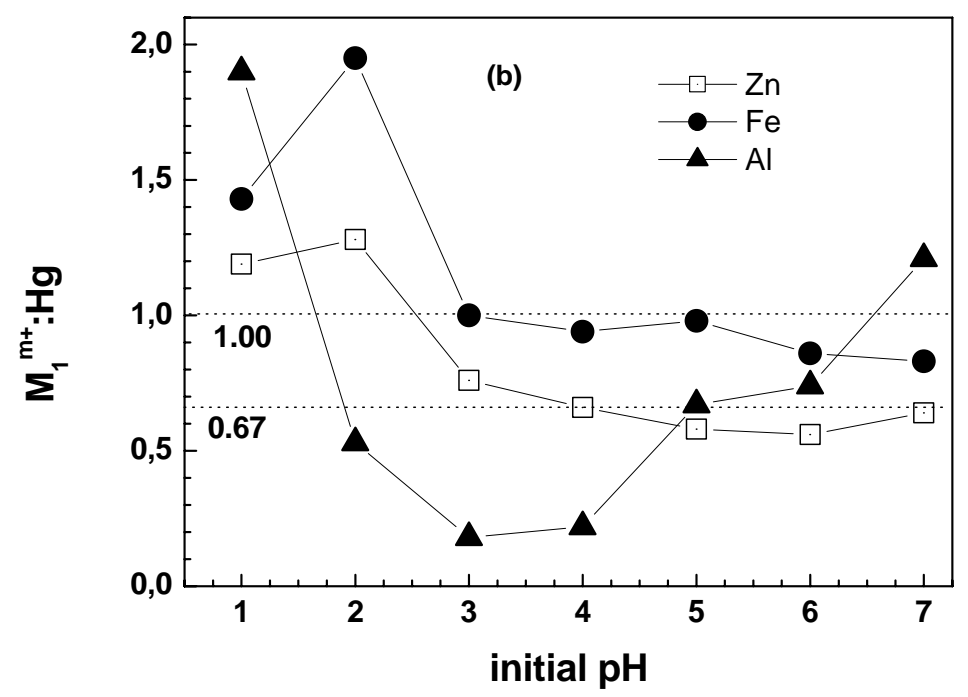

408

Figure 1: Final $\mathrm{pH}$ value (a) and molar ratio dissolved metal to cemented $\mathrm{Hg}$ (b) with different initial $\mathrm{pH}$ values. The lines are not fitting functions, they simply connect points to facilitate visualization. Data from ref. [50]. 